九州大学学術情報リポジトリ

Kyushu University Institutional Repository

\title{
Enhancement of Power Generation in Microbial Fuel Cells (Mfcs) Using Iron/Copper Nanoparticles
}

Bensaida, Khaoula

Department of Earth System Science and Technology, Interdisciplinary Graduate School of Engineering Sciences, Kyushu University

Falyouna, Omar

Department of Earth System Science and Technology, Interdisciplinary Graduate School of Engineering Sciences, Kyushu University

Maamoun, Ibrahim

Department of Earth System Science and Technology, Interdisciplinary Graduate School of Engineering Sciences, Kyushu University

Eljamal, Ramadhan

Department of Earth System Science and Technology, Interdisciplinary Graduate School of Engineering Sciences, Kyushu University

他

https://doi.org/10.5109/4102482

出版情報: Proceedings of International Exchange and Innovation Conference on Engineering \& Sciences (IEICES). 6, pp. 156-162, 2020-10-22. Interdisciplinary Graduate School of Engineering Sciences, Kyushu University

バージョン:

権利関係 : 


\title{
Enhancement of Power Generation in Microbial Fuel Cells (Mfcs) Using Iron/Copper Nanoparticles
}

\author{
Khaoula Bensaida, Omar Falyouna, Ibrahim Maamoun, Ramadhan Eljamal, Osama Eljamal* \\ Department of Earth System Science and Technology, Interdisciplinary Graduate School of Engineering Sciences, \\ Kyushu University \\ Corresponding author e-mail: osama-eljamal@kyudai.jp
}

\begin{abstract}
In this study, a lab-scale microbial fuel cell (MFC) was constructed and power generation output was investigated for 45 days of operation. Nanoscale zerovalent iron (NZVI) and Iron/copper nanoparticles (Cu/NZVI) were added to the anode chamber of the MFC with a concentration of $10 \mathrm{mg} / \mathrm{L}$ and their effects were investigated on the MFC performance. Results showed that the maximal power output density values increased by $43.33 \%$ using copper/iron nanoparticles compared to the control MFC. Anode chamber was examined, and results proved that conductivity increased by $13.68 \%$ and $23.62 \%$ using NZVI and Cu/NZVI, respectively. The chemical oxygen demand COD was tested, and the removal efficiency reached $38.88 \%, 38.26 \%$, and $52.40 \%$ for control, NZVI, and Cu/NZVI MFCs, respectively after 45 days of operation. This study highlights the effect of nanoparticles technology on power generation from activated sludge using microbial fuel cells (MFCs).
\end{abstract}

Keywords: Activated sludge; conductivity; chemical oxygen demand; power density; microbial fuel cell.

\section{INTRODUCTION}

Due to the depletion of energy resources and the increase in the energy consumption, many studies are focusing on the improvement and the development of many sustainable technologies. In this context, microbial fuel cells (MFCs) are emerging as a promising technology for bioelectricity generation from wastewater [1],[2],[3]. This is particularly because MFCs technology can harvest energy from organic matter through bacterial metabolism. MFCs are electrochemical devices that are typically composed of two chambers: the anode chamber which is maintained under anaerobic conditions and contains the living microorganisms whereas the cathode chamber is usually maintained under aerobic conditions. The two chambers are separated by a proton exchange membrane PEM that ideally allows the protons to pass from the anode to the cathode chamber and limit the oxygen leakage from the cathode to the anode side. [4],[5]. The bacteria present the powerhouse of the MFC technology [6]. Exoelectrogens are the biocatalysts that degrade the organic matter and as products, electrons and protons are released through this oxidation. Due to the extracellular electron transfer (EET), the produced electrons transfer from the biofilm side to the anode surface, and then flow all along the external circuit to the cathode. On the other side, protons will transfer through the membrane to the cathode chamber. The two mechanisms are summarized in the two equations below[7]:

(Anode): Organic matter $+\mathrm{H}_{2} \mathrm{O} \rightarrow \mathrm{e}^{-}+\mathrm{H}^{+}+\mathrm{CO}_{2}$

(Cathode): $\quad \mathrm{O}_{2}+4 \mathrm{H}^{+}+4 \mathrm{e}^{-} \rightarrow 2 \mathrm{H}_{2} \mathrm{O}$

MFCs are considered as promising technologies for both electricity generation and wastewater treatment. The use of wastewater as a fuel to harvest power is considered an environmentally friendly technique that should be developed and improved. Tremendous advances have been made to improve MFCs performance. Many MFC system configurations were investigated. System conditions were varied, and electrode materials and surfaces were optimized [8],[9], [10]. However, many challenges are still facing the MFC technology. In fact, the system performance is still not reaching researchers expectations. High internal resistance, low current output, stability, and low electron transfer are the main challenges. Many factors are behind the low efficiency of the system. One major reason is that the electrons released through the oxidation of the organic matter are not well transferred from the biofilm side to the electrode surface [11],[12]. The poor ability of electron transfer in the anode chamber affects the power performance of the MFC system. Indeed, the principle working of MFCs is mainly based on the use of microorganisms as biocatalyst to digest the organic matter and transfer electrons from the biofilm side to the anode surface. Many research studies have been focusing on improving the system performance by enhancing the EET and reducing the internal resistivity. In fact, the organic matter degradation, electron transfer, and the proton migration are key steps in MFC performance. Therefore, to increase the power performance, the microbial community changes in wastewater have been examined and electron transfer techniques were studied. Three different mechanisms of electron transfer have been defined so far in the literature [13] and the electrons given off during the anaerobic oxidation can reach the anode surface either by direct transfer mechanism (DET), mediated electron transfer mechanism (MET), or they can be exported through nanowires.

The focus point of this study is to improve the overall system performance. A way to enhance the power output is adding iron nanoparticles defined as nanoscale zerovalent iron (NZVI) to the anode chamber of the MFC, as its one of the key factors that determine the power output. NZVI have been widely used in wastewater treatment and bioremediation. Their large surface area and high reactivity were effective to remove contaminants from wastewater and enhance their biodegradability [14],[15],[16],[17],[18]. The reactivity 
of NZVI particles can be enhanced by adding another metal to form the so-called bimetallic nanoparticles [19],[20], [21]. A small amount of these metals applied to the NZVI will cause an increase in the reactivity of the formed alloy and will provide a good protection against corrosion and passivation. Among the most used metals, copper has been used due to its ecofriendly sustainability, cost effectiveness and high reactivity. In [22], the alloy iron/copper was used to examine its effect on the wastewater microbial life, contaminants removal, and the organic matter degradation. Results of the study showed that using iron/copper bimetal with $10 \mathrm{mg} / \mathrm{L}$ increased the phosphorus removal. Also, the study showed that $\mathrm{Cu} / \mathrm{NZVI}$ had a positive impact on increasing the bacterial growth rate [23].

In this study, bimetallic iron copper nanoparticles were added to the anode chamber of an MFC and their effect on the system performance and power generation was studied. As a comparison, bare iron nanoparticles were utilized. The power performance of the MFC was assessed by power density output and chemical oxygen demand (COD). It is expected that adding these nanoparticles will enhance the voltage output by playing a trace element for bacteria, reducing the anode chamber resistivity, and facilitating the electron transfer from the biofilm to the anode surface.

\section{MATERIALS \& METHODS}

\subsection{Reagents \& materials}

The sludge used in this study was obtained from Mikasagawa domestic wastewater purification center located in the city of Fukuoka, Japan. The sludge was kept at a temperature under $4^{\circ} \mathrm{C}$ to keep its freshness and inhibit the bacterial growth all along the period of experiments. The following reagents were used for the NZVI and $\mathrm{Cu} / \mathrm{NZVI}$ synthesis: sodium borohydride (NaBH4>99.0\%, Junsei Chemical Co., Japan ), ferric chloride ( $>99.0 \%$, Junsei Chemical Co., Japan), copper( II ) chloride (Purity $=99.9 \%$, Sigma Aldrich, USA). Hydrochloric acid (35-37\%, Wako Co., Japan) was used for $\mathrm{pH}$ adjustment. Nitrogen gas was used for deoxygenating the deionized water through bubbling for 10 minutes. Standard Plate Count Agar (APHA) CM0463 (OXOID LTD., England) was used for bacterial growth measuring. COD Digestion Reagents Vials HACH4236 COD HR 25 were used to measure the chemical oxygen demand (COD) removal efficiency.

\subsection{Synthesis of NZVI and Cu/NZVI nanoparticles}

The synthesis was conducted according to the optimization process in our previous study [24], [25], [26]. The NZVI particles were prepared, at a specific temperature using a water bath of $30 \mathrm{oC}$, by the chemical reduction of $0.093 \mathrm{M} \mathrm{FeCl} 3.6 \mathrm{H} 2 \mathrm{O}$ by $0.58 \mathrm{M}$ $\mathrm{NaBH} 4$.following the reaction below (1):

$4 \mathrm{Fe} 3++3 \mathrm{BH} 4-+9 \mathrm{H} 2 \mathrm{O} \rightarrow 4 \mathrm{Fe}^{\circ} \downarrow+3 \mathrm{H} 2 \mathrm{BO} 3-+12 \mathrm{H}++6 \mathrm{H} 2 \uparrow$ (3)

The sodium borohydride solution was added to ferric chloride solution dropwise $(20 \mathrm{~mL} / \mathrm{min})$ using a peristaltic pump. A continues nitrogen purging was provided to ensure anaerobic conditions. NZVI precipitates were formed by the 400 RPM vigorous mixing during the whole synthesis time at $30 \pm 0.5 \mathrm{oC}$. Vacuum filtration was used for the particles separating after washing with deionized water (DIW). The bimetallic nanoparticles were prepared by adding the mentioned reagents above to the $\mathrm{FeCl} 3 \cdot 6 \mathrm{H} 2 \mathrm{O}$ solution. The iron/copper ratio was $5 \%$ by weight. The iron/copper nanoparticles were synthesized under anaerobic conditions [22].

\subsection{Sludge characterization}

The anode chamber was fed with a real sludge collected from the wastewater plant. The following table summarizes the initial values of the sludge characteristics before adding the nanoparticles to the anode chamber.

Table 1. Sludge initial characterization.

\begin{tabular}{lcc}
\hline \hline Parameter & Unit & Value \\
\hline$p H$ & - & 7.17 \\
ORP & $\mathrm{mV}$ & -38 \\
Conductivity & $\mu \mathrm{S} / \mathrm{cm}$ & 794.60 \\
Resistivity & $\Omega . \mathrm{cm}^{2}$ & 1000 \\
Salinity & $\mathrm{ppt}$ & 0.5 \\
$T D S$ & $\mathrm{mg} / \mathrm{L}$ & 397 \\
$T S$ & $\mathrm{~g} / \mathrm{L}$ & 4.37 \\
$T V S$ & $\mathrm{~g} / \mathrm{L}$ & 3.60 \\
$C O D$ & $\mathrm{mg} / \mathrm{L}$ & 5849 \\
$F e^{2+}$ & $\mathrm{mg} / \mathrm{L}$ & 21.68 \\
$F e$ & $\mathrm{mg} / \mathrm{L}$ & 42.89 \\
& & \\
\hline \hline
\end{tabular}

\subsection{MFC configuration and operation}

Three double-chamber MFCs were used in this study. Each MFC was built in H-type consisting of two glass bottles with a volume of $500 \mathrm{~mL}$ each, and separated by a proton exchange membrane (Nafion, 117 proton). A copper was used to connect the two electrodes, linked with an external resistance of 200 ohms. The two electrodes were made from carbon felt with a surface area equal to $24 \mathrm{~cm}^{2}$. All MFCs were operated in a batch mode at a constant incubator temperature $40 \mathrm{oC}$, for 45 days of operation. Iron nanoparticles and $\mathrm{Cu} / \mathrm{NZVI}$ were added to the anode chamber with a concentration of $10 \mathrm{mg} / \mathrm{L}$. A magnetic stirring was used to keep the homogeneity of the anolyte and to the inhibit the precipitation of the sludge components as well as the added nanoparticles. At the beginning of the experiments, the nitrogen gas was bubbled for 10 minutes to ensure anaerobic conditions for the anode chamber. Then all MFCs were sealed. The cathode chamber was filled with deionized water and kept closed all along the period of experiments. The MFC without additives served as the control.

\subsection{Calculation and electrochemical characterization}

The voltage output (V) was recorded every day using a multimeter. According to ohm's law, the current (I=V/R) and the power output $(\mathrm{P}=\mathrm{VI})$ were calculated using the external resistance $\mathrm{R}$ and the measure voltage $\mathrm{V}$. The power density $\mathrm{P}_{\mathrm{an}}\left(\mathrm{mW} / \mathrm{m}^{2}\right)$ was normalized to the anodic surface area following the equation below:

$$
\mathrm{P}_{a n}=\frac{V^{2}}{\operatorname{Aan} R}
$$

Where: $\mathrm{V}$ is the measured voltage $(\mathrm{mV}), \mathrm{A}_{\mathrm{an}}$ is the anode 
surface area $\left(\mathrm{cm}^{2}\right)$, and $\mathrm{R}$ is the external resistance $(\Omega)$.

Conductivity, resistivity, total dissolved solid (TDS), and salinity were measured using conductivity meter. $\mathrm{pH}$ and ORP values were recorded using $\mathrm{pH}$ meter. COD removal, total solid (TS), and total volatile solids (TVS) in the anode chamber were measured following the standard methods. The coulombic efficiency was measured as the ratio between the experimentally measured coulombic values transferred from the microorganisms to the anode surface and the theoretically produced electrons from the degradation of the organic matter in the anode chamber as detailed in the equation below:

$$
\mathrm{CE}=\frac{M \int_{0}^{t} I d t}{\mathrm{~F} \mathrm{~b} \operatorname{Van} \Delta \mathrm{COD}}
$$

Where: $\mathrm{M}$ is the oxygen molecular weight $(32 \mathrm{~g} / \mathrm{mol}), \mathrm{F}$ is the Faraday's constant $(96485.34 \mathrm{C} / \mathrm{mol})$, $b$ is equal to 4 and it indicates the number of electrons exchanged per mole of oxygen, and Van is the anode chamber volume $(500 \mathrm{ml})$. The concentrations of ferrous, ferric, and total dissolved iron were recorded using a UV spectrophotometer. The bacterial growth was examined using the counting plate method.

\section{RESULTS \& DISCUSSION}

\subsection{Effect of nanoparticles on power generation}

Figure 1 illustrates the variation of voltage output amplitude for control, NZVI, and Cu/NZVI MFCs. The voltage maximum value was equal to 25.6 and $54 \mathrm{mV}$ using NZVI, and $\mathrm{Cu} / \mathrm{NZVI}$ nanoparticles, respectively. Therefore, adding iron nanoparticles to the anode chamber led to a decrease in the voltage output by $18.99 \%$ compared to the control values, whereas using the bimetallic nanoparticles enhanced the voltage output by $43.33 \%$. The effect of iron/copper was highlighted in table 2 where the total measured coulombic $\mathrm{Cp}$, the maximum voltage, current, and power values were measured based on the experimental data. The maximal power density output $\mathrm{P}_{\mathrm{an}}$ increased by $65.57 \%$ when anode chamber was exposed to iron/copper treatment.

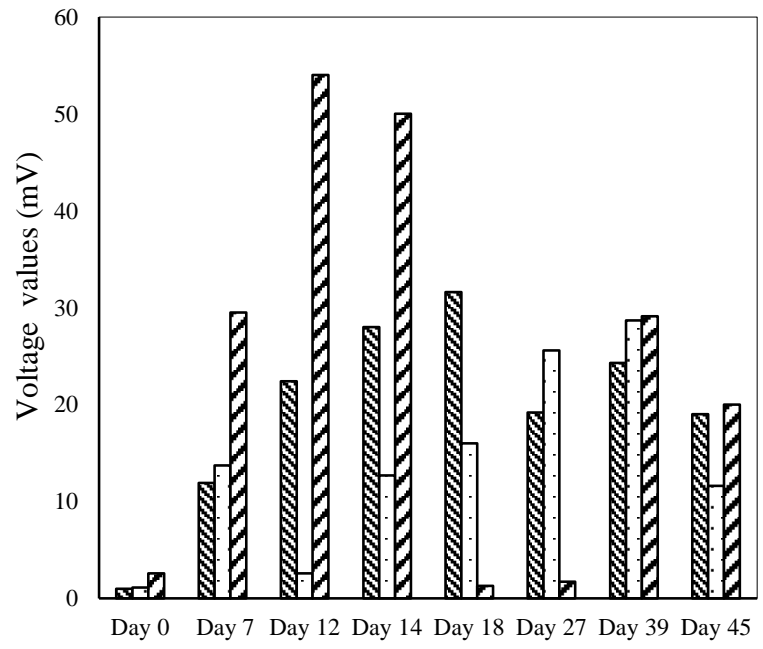

\$Control $\square$ NZVI $\square \mathrm{Cu} / \mathrm{NZVI}$

Fig. 1: Voltage generation in MFCs using nZVI and $\mathrm{Cu} / \mathrm{nZVI}$ nanoparticles at the anode throughout the operation period.

Table 2. Measurements values recorded and calculated from the experiments.

\begin{tabular}{llccc}
\hline \hline Parameter & Unit & Control & NZVI & $\mathrm{Cu} / \mathrm{NZVI}$ \\
& & & & \\
\hline$C p$ & $\mathrm{C}$ & 4.412 & 3.58 & 4.25 \\
$\operatorname{Vmax}$ & $\mathrm{mV}$ & 31.60 & 25.60 & 54.00 \\
$P \max$ & $\mu \mathrm{W}$ & 5.05 & 3.33 & 14.60 \\
$I \max$ & $\mathrm{mA}$ & 0.16 & 0.13 & 0.27 \\
$\triangle C O D$ & $\mathrm{Mg} / \mathrm{L}$ & 2274 & 2238 & 3065 \\
$P_{a n}$ & $\mathrm{~mW} / \mathrm{m}^{2}$ & 2.10 & 1.40 & 6.10 \\
$P_{\text {g.vs }}$ & $\mu \mathrm{W} / \mathrm{g} . \mathrm{vs}$ & 2.77 & 1.82 & 8.10 \\
\hline \hline
\end{tabular}
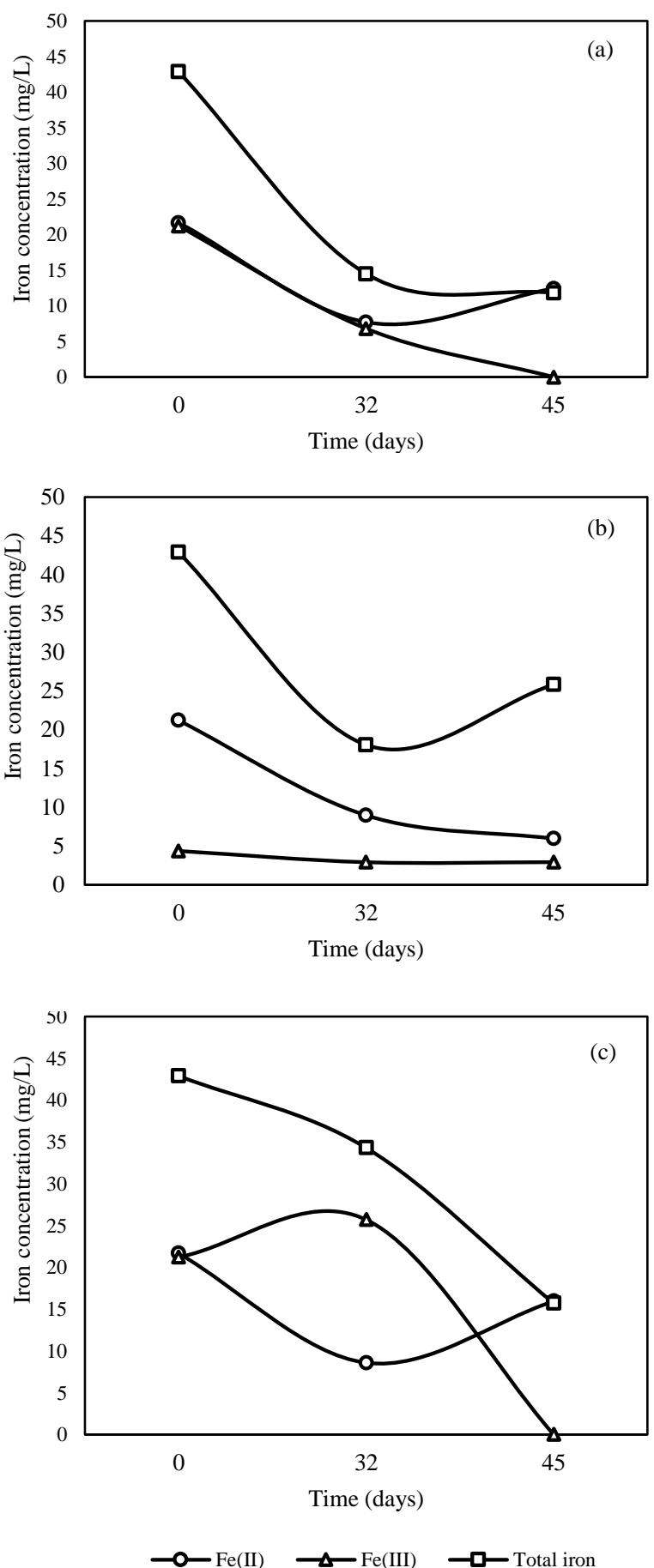

Fig. 2: Iron concentration in the anode chamber throughout the operation period: (a) the control 
MFC, (b) NZVI MFC, and (c) Cu/NZVI MFC.

As shown in figure 2, the iron concentration did not stay constant and it decreased by time. At the beginning of the experiments, the ratio of ferric/ferrous ions was around $50 \%$, and then, the ferric ions concentration decreased during the operation days to become almost null in the control and $\mathrm{Cu} / \mathrm{NZVI}$ MFCs. After 45 days, the total iron was in the form of ferrous ions. This can be explained by the high reduction rate of ferric ions throughout the experimental days. The reduction of the ferric/ferrous ratio can be attributed to the high released electrons in the anode chamber resulted from the anaerobic digestion of the organic matter, and as a result, a high reduction rate of ferric ions occurred. This can explain that ferric ions played the role of an electron carrier to transfer electrons from the biofilm side to the anode surface. However, the high reduction can affect the overall performance of the MFC, since the biological reduction rate of ferric ions is high enough to limit the produced current [27],[28],[29].

Table 3. Anode chamber characteristics after 45 days of operation

\begin{tabular}{llccc}
\hline \hline Parameter & Unit & Control & NZVI & $\mathrm{Cu} / \mathrm{NZVI}$ \\
& & & & \\
\hline Conductivity & $\mu \mathrm{S} / \mathrm{cm}$ & 1022 & 1184 & 1338 \\
Resistivity & $\Omega . \mathrm{cm}^{2}$ & 979 & 848 & 748 \\
Salinity & $\mathrm{ppt}$ & 0.7 & 0.8 & 0.9 \\
$T D S$ & $\mathrm{mg} / \mathrm{L}$ & 511 & 593 & 670 \\
$T S$ & $\mathrm{~g} / \mathrm{L}$ & 3.28 & 2.93 & 2.65 \\
$T V S$ & $\mathrm{~g} / \mathrm{L}$ & 2.49 & 2.09 & 1.90 \\
$p H$ & - & 7.12 & 7.26 & 7.17 \\
ORP & $\mathrm{mV}$ & -34 & -42 & -36 \\
\hline \hline
\end{tabular}

Table 3 summarizes the anolyte chamber characteristics at the end of the experiments. The enhancement of the power generation using $\mathrm{Cu} / \mathrm{NZVI}$ can be attributed to the increase in the conductivity values, and a decrease in the resistivity of the anolyte. In fact, using copper/iron nanoparticles enhanced the conductivity by $23.62 \%$ compared to just $13.68 \%$ using bare iron nanoparticles. This is mainly attributed to high dispersibility, ductile chain, and the low agglomeration of $\mathrm{Cu} / \mathrm{NZVI}$ compared to the bare iron particles structure. Figure 3 presents the reduction in the resistivity values within time.

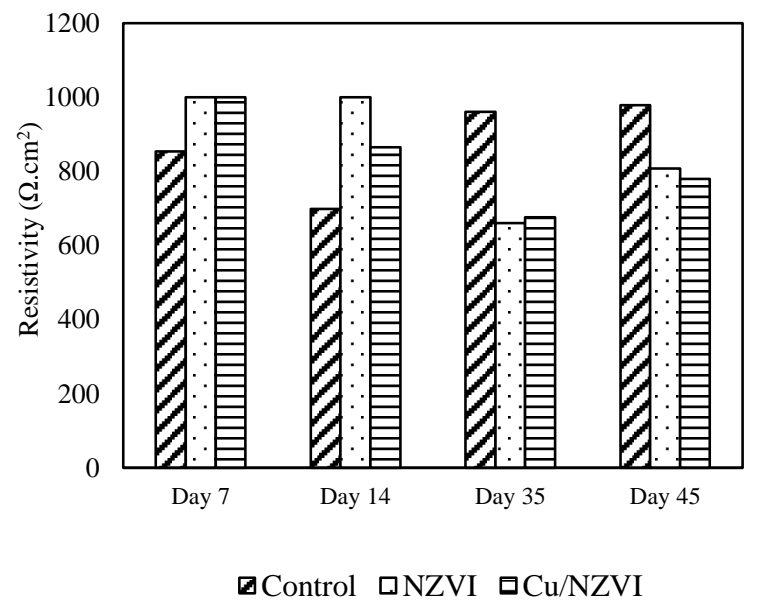

Fig. 3: Resistivity values in the anode chamber throughout the operation period for the control MFC,
NZVI MFC, and Cu/NZVI MFC.

Also, the high concentration of the ions dissolved inside the anode chamber increased by $23.73 \%$ using $\mathrm{Cu} / \mathrm{NZVI}$, whereas NZVI particles enhanced the TDS by just $13.83 \%$. This highlights the effective bimetallic nanoparticles reactivity with organic matter compounds [30],[31],[32].

In a further step, bacterial growth response to the nanoparticles treatment was examined and results showed that iron nanoparticles stimulate the active bacteria. As shown in figure 4, the maximum number of colonies increased by $93.35 \%$ and $95 \%$ using NZVI and $\mathrm{Cu} / \mathrm{NZVI}$, respectively. Iron nanoparticles presented a trace element for bacteria. In fact, NZVI, added within a determined dose enhance the bacterial growth by maintaining a lower ORP level and a neutral $\mathrm{pH}$ conditions [33],[34],[35].

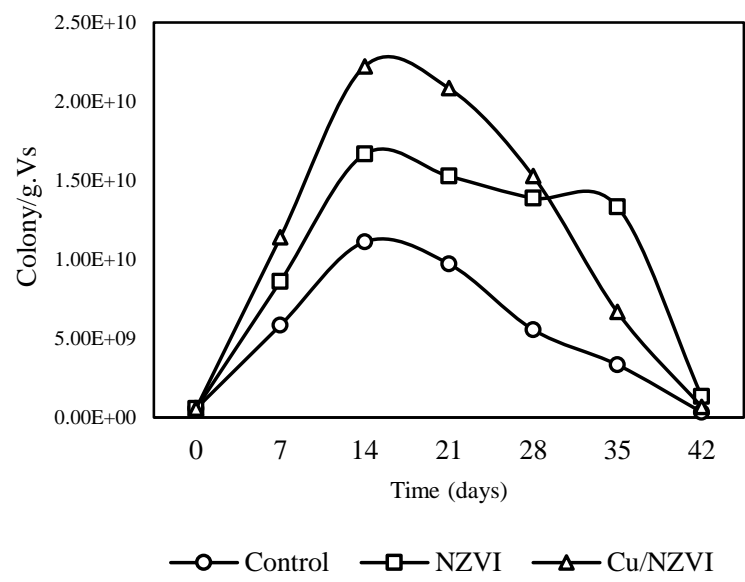

Fig. 4: Bacterial growth in the anode chamber under anaerobic conditions during the operation period when exposed to: (a) the control MFC, (b) NZVI MFC, and (c) $\mathrm{Cu} / \mathrm{NZVI}$ MFC.

\subsection{Effect of NZVI and Cu/NZVI on wastewater treatment}

The performance of the constructed MFCs was evaluated in terms of wastewater treatment and organic matter biodegradability. Figure 5 illustrates the COD removal efficiencies values in day 15 , day 32 , and at the end of the experiments.

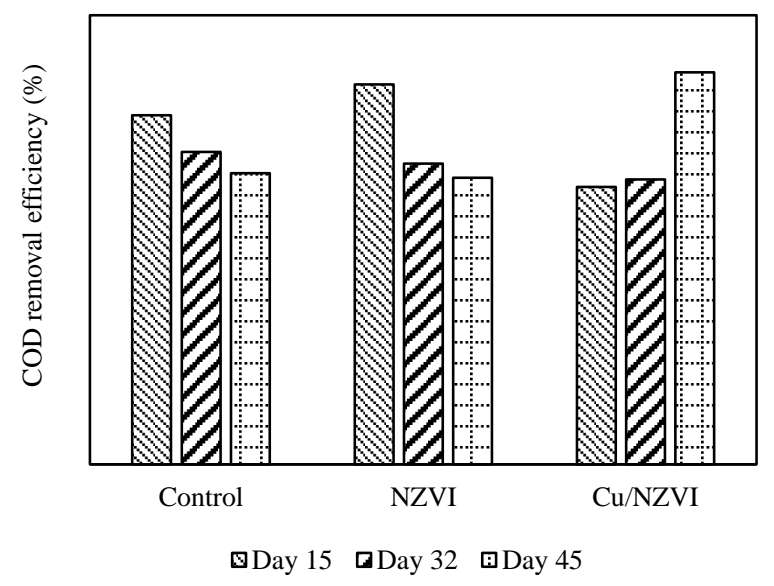

Fig. 5: COD removal efficiencies in the anode chamber throughout the operation period for the control MFC, 
NZVI MFC, and Cu/NZVI MFC.

After 15 days of operation, the removal efficiency reached $46.62 \%, 50.78 \%, 37.07 \%$, and for control, NZVI, and Cu/NZVI MFCs, respectively. At the end of experiments, the COD removal efficiency was $38.88 \%$, $38.26 \%$, and $52.40 \%$ for control, NZVI, and Cu/NZVI MFCs, respectively. The increase in the organic matter degradation can be explained by the increase in the bacterial cells number and the positive effect of nanoparticles recorded on the activity of bacterial colonies [36],[37],[38]. The organic matter degradation was examined through total solid and total volatile solid measurements (table 3 ). Results proved that the TVS was reduced by $30.83 \%, 41.94 \%$, and $47.22 \%$ for control, NZVI, and $\mathrm{Cu} / \mathrm{NZVI}$, respectively. The high matter degradation will enhance the number of released electrons as a product of the anaerobic digestion, and thus the power output will be enhanced [39],[40].

\section{CONCLUSION}

MFCs are a promising technology for power generation and wastewater treatment. However, many challenges are facing this technology. The high internal resistivity and low power generation still the main concerns of all researchers. In our study, iron nanoparticles were added to the anode chamber and their effect was investigated. Their reactivity was enhanced by using copper /iron bimetallic nanoparticles. Results proved that maximum voltage value increased by $43.33 \%$. using $\mathrm{Cu} / \mathrm{NZVI}$. In addition, the power density was enhanced by $65.57 \%$ when anode chamber was exposed to iron/copper treatment. However, the overall performance was not high as it is expected. This can be explained by the ferric iron's reduction and the biomass growth which increased the internal resistivity of the anode chamber.

\section{REFERENCES}

[1] B.E. Logan, B. Hamelers, R. Rozendal, U. Schröder, J. Keller, S. Freguia, P. Aelterman, W. Verstraete, K. Rabaey, Microbial fuel cells: Methodology and technology, Environ. Sci. Technol. 40 (2006) 5181-5192. https://doi.org/10.1021/es0605016.

[2] D. Pant, G. Van Bogaert, L. Diels, K. Vanbroekhoven, A review of the substrates used in microbial fuel cells (MFCs) for sustainable energy production, Bioresour. Technol. 101 (2010) 1533-1543. https://doi.org/10.1016/j.biortech.2009.10.017.

[3] T. Tommasi, G. Lombardelli, Energy sustainability of Microbial Fuel Cell (MFC): A case study, J. Power Sources. 356 (2017) 438447.

https://doi.org/10.1016/j.jpowsour.2017.03.122.

[4] D. Liu, Q. Chang, Y. Gao, W. Huang, Z. Sun, M. Yan, C. Guo, High performance of microbial fuel cell afforded by metallic tungsten carbide decorated carbon cloth anode, Electrochim. Acta. 330 (2020) 135243. https://doi.org/10.1016/j.electacta.2019.135243.

[5] Q. Deng, C. Su, X. Lu, W. Chen, X. Guan, S. Chen, M. Chen, Performance and functional microbial communities of denitrification process of a novel MFC-granular sludge coupling system, Bioresour. Technol. 306 (2020) 123173.

https://doi.org/10.1016/j.biortech.2020.123173.

[6] Q. Liu, Y. Yang, X. Mei, B. Liu, C. Chen, D. Xing, Response of the microbial community structure of biofilms to ferric iron in microbial fuel cells, Sci. Total Environ. 631-632 (2018) 695-701.

https://doi.org/10.1016/j.scitotenv.2018.03.008.

[7] R. Kumar, L. Singh, A.W. Zularisam, F.I. Hai, Microbial fuel cell is emerging as a versatile technology: a review on its possible applications, challenges and strategies to improve the performances, Int. J. Energy Res. 42 (2018) 369-394. https://doi.org/10.1002/er.3780.

[8] S. Gadkari, J.M. Fontmorin, E. Yu, J. Sadhukhan, Influence of temperature and other system parameters on microbial fuel cell performance: Numerical and experimental investigation, Chem. Eng. J. 388 (2020) 124176. https://doi.org/10.1016/j.cej.2020.124176.

[9] N. Xiao, P.R. Selvaganapathy, R. Wu, J.J. Huang, Influence of wastewater microbial community on the performance of miniaturized microbial fuel cell biosensor, Bioresour.

Technol. 302 (2020) 122777.

https://doi.org/10.1016/j.biortech.2020.122777.

[10] H. Liu, B.E. Logan, Electricity generation using an air-cathode single chamber microbial fuel cell in the presence and absence of a proton exchange membrane, Environ. Sci. Technol. 38 (2004) 4040-4046. https://doi.org/10.1021/es0499344.

[11] Y. Yang, M. Xu, J. Guo, G. Sun, Bacterial extracellular electron transfer in bioelectrochemical systems, Process Biochem. 47 (2012) 1707-1714.

https://doi.org/10.1016/j.procbio.2012.07.032.

[12] M. Li, M. Zhou, X. Tian, C. Tan, C.T.

McDaniel, D.J. Hassett, T. Gu, Microbial fuel cell (MFC) power performance improvement through enhanced microbial electrogenicity, Biotechnol. Adv. 36 (2018) 1316-1327. https://doi.org/10.1016/j.biotechadv.2018.04.01 0 .

[13] P. Srivastava, R. Abbassi, A.K. Yadav, V. Garaniya, M. Asadnia, A review on the contribution of electron flow in electroactive wetlands: Electricity generation and enhanced wastewater treatment, Chemosphere. 254 (2020) 126926.

https://doi.org/10.1016/j.chemosphere.2020.126 926.

[14] R.A. Crane, T.B. Scott, Nanoscale zero-valent iron: Future prospects for an emerging water treatment technology, J. Hazard. Mater. 211212 (2012) 112-125. https://doi.org/10.1016/j.jhazmat.2011.11.073.

[15] X. Zhao, W. Liu, Z. Cai, B. Han, T. Qian, D. Zhao, An overview of preparation and applications of stabilized zero-valent iron nanoparticles for soil and groundwater remediation, Water Res. 100 (2016) 245-266. https://doi.org/10.1016/j.watres.2016.05.019. 
[16] C.S. He, P.P. He, H.Y. Yang, L.L. Li, Y. Lin, Y. $\mathrm{Mu}, \mathrm{H} . \mathrm{Q}$. Yu, Impact of zero-valent iron nanoparticles on the activity of anaerobic granular sludge: From macroscopic to microcosmic investigation, Water Res. 127 (2017) 32-40.

https://doi.org/10.1016/j.watres.2017.09.061.

[17] Y. Zhao, Z. Zhao, X. Song, X. Jiang, Y. Wang, X. Cao, Z. Si, F. Pan, Effects of nZVI dosing on the improvement in the contaminant removal performance of constructed wetlands under the dye stress, Sci. Total Environ. 703 (2020) 134789.

https://doi.org/10.1016/j.scitotenv.2019.134789.

[18] O. Eljamal, A.M.E. Khalil, N. Matsunaga, Experimental and Modeling Column Study of Phosphorus Removal by Permeable Reactive Materials, Int. J. Environ. Agric. Res. ISSN. 3 (2017) 62-70.

[19] A. Al-Asfar, Z. Zaheer, E.S. Aazam, Ecofriendly green synthesis of Ag@Fe bimetallic nanoparticles: Antioxidant, antimicrobial and photocatalytic degradation of bromothymol blue, J. Photochem. Photobiol. B Biol. 185 (2018) 143-152. https://doi.org/10.1016/j.jphotobiol.2018.05.028

[20] L. Chen, R. Ni, T. Yuan, Y. Gao, W. Kong, P. Zhang, Q. Yue, B. Gao, Effects of green synthesis, magnetization, and regeneration on ciprofloxacin removal by bimetallic $n Z \mathrm{VI} / \mathrm{Cu}$ composites and insights of degradation mechanism, J. Hazard. Mater. 382 (2020) 121008. https://doi.org/10.1016/j.jhazmat.2019.121008.

[21] O. Eljamal, J. Okawauchi, K. Hiramatsu, Removal of Phosphorus from Water Using Marble Dust as Sorbent Material, J. Environ. Prot. (Irvine,. Calif). 03 (2012) 709-714. https://doi.org/10.4236/jep.2012.38084.

[22] T.W.M. Amen, O. Eljamal, A.M.E. Khalil, N. Matsunaga, Wastewater degradation by iron/copper nanoparticles and the microorganism growth rate, J. Environ. Sci. (China). 74 (2018) 19-31. https://doi.org/10.1016/j.jes.2018.01.028.

[23] O. Eljamal, I.P. Thompson, I. Maamoun, T. Shubair, K. Eljamal, K. Lueangwattanapong, Y. Sugihara, Investigating the design parameters for a permeable reactive barrier consisting of nanoscale zero-valent iron and bimetallic iron/copper for phosphate removal, J. Mol. Liq. 299 (2020) 112144. https://doi.org/10.1016/j.molliq.2019.112144.

[24] R. Eljamal, O. Eljamal, A.M.E. Khalil, B.B. Saha, N. Matsunaga, Improvement of the chemical synthesis efficiency of nano-scale zero-valent iron particles, J. Environ. Chem. Eng. 6 (2018) 4727-4735. https://doi.org/10.1016/j.jece.2018.06.069.

[25] A.M.E. Khalil, O. Eljamal, B.B. Saha, N. Matsunaga, Performance of nanoscale zerovalent iron in nitrate reduction from water using a laboratory-scale continuous-flow system, Chemosphere. 197 (2018) 502-512. https://doi.org/10.1016/j.chemosphere.2018.01. 084.

[26] O. Eljamal, K. Sasaki, T. Hirajima, Sorption Kinetic of Arsenate as Water Contaminant on Zero Valent Iron, J. Water Resour. Prot. 05 (2013) 563-567.

https://doi.org/10.4236/jwarp.2013.56057.

[27] W. Qi, J. Long, C. Feng, Y. Feng, D. Cheng, Y. Liu, J. Xue, Z. Li, Fe3+ enhanced degradation of oxytetracycline in water by pseudomonas, Water Res. 160 (2019) 361-370. https://doi.org/10.1016/j.watres.2019.05.058.

[28] Y. Lv, Y. Lin, L. Yang, Z. Cai, B. Jing, J. Yu, X. Jiang, Z. Xing, J. Zou, Iron (III) metaphosphate/iron phosphide heterojunctions embedded in partly-graphitized carbon for enhancing charge transfer and power generation in microbial fuel cells, Chem. Eng. J. 342 (2018) 228-237. https://doi.org/10.1016/j.cej.2018.02.083.

[29] H.O. Mohamed, M. Obaid, K.M. Poo, M. Ali Abdelkareem, S.A. Talas, O.A. Fadali, H.Y. $\mathrm{Kim}, \mathrm{K} . J$. Chae, $\mathrm{Fe} / \mathrm{Fe} 2 \mathrm{O} 3$ nanoparticles as anode catalyst for exclusive power generation and degradation of organic compounds using microbial fuel cell, Chem. Eng. J. 349 (2018) 800-807. https://doi.org/10.1016/j.cej.2018.05.138.

[30] Y. Su, A.S. Adeleye, Y. Huang, X. Sun, C. Dai X. Zhou, Y. Zhang, A.A. Keller, Simultaneous removal of cadmium and nitrate in aqueous media by nanoscale zerovalent iron (nZVI) and Au doped nZVI particles, Water Res. 63 (2014) 102-111. https://doi.org/10.1016/j.watres.2014.06.008.

[31] O. ELJAMAL, K. JINNO, T. HOSOKAWA, Modeling of Biologically Mediated Redox Processes Using Sawdust As a Matrix, Proc. Hydraul. Eng. 51 (2007) 19-24.

https://doi.org/10.2208/prohe.51.19.

[32] O. Eljamal, T. Shubair, A. Tahara, Y. Sugihara, N. Matsunaga, Iron based nanoparticles-zeolite composites for the removal of cesium from aqueous solutions, J. Mol. Liq. 277 (2019) 613623.

https://doi.org/10.1016/j.molliq.2018.12.115.

[33] K. Chaithawiwat, A. Vangnai, J.M. McEvoy, B. Pruess, S. Krajangpan, E. Khan, Impact of nanoscale zero valent iron on bacteria is growth phase dependent, Chemosphere. 144 (2016) 352-359. https://doi.org/10.1016/j.chemosphere.2015.09. 025 .

[34] J. Zhou, X. You, B. Niu, X. Yang, L. Gong, Y. Zhou, J. Wang, H. Zhang, Enhancement of methanogenic activity in anaerobic digestion of high solids sludge by nano zero-valent iron, Sci. Total Environ. 703 (2020) 135532. https://doi.org/10.1016/j.scitotenv.2019.135532.

[35] M.T. Gómez-Sagasti, L. Epelde, M. Anza, J. Urra, I. Alkorta, C. Garbisu, The impact of nanoscale zero-valent iron particles on soil microbial communities is soil dependent, $\mathrm{J}$. Hazard. Mater. 364 (2019) 591-599. https://doi.org/10.1016/j.jhazmat.2018.10.034. 
[36] A. Najafpoor, R. Norouzian-Ostad, H. Alidadi, T. Rohani-Bastami, M. Davoudi, F. BarjastehAskari, J. Zanganeh, Effect of magnetic nanoparticles and silver-loaded magnetic nanoparticles on advanced wastewater treatment and disinfection, J. Mol. Liq. 303 (2020) 112640 . https://doi.org/10.1016/j.molliq.2020.112640.

[37] Y. Sun, J. Li, T. Huang, X. Guan, The influences of iron characteristics, operating conditions and solution chemistry on contaminants removal by zero-valent iron: A review, Water Res. 100 (2016) 277-295. https://doi.org/10.1016/j.watres.2016.05.031.

[38] Y. Lv, Z. Niu, Y. Chen, Y. Hu, Bacterial effects and interfacial inactivation mechanism of nZVI/Pd on Pseudomonas putida strain, Water Res. 115 (2017) 297-308.

https://doi.org/10.1016/j.watres.2017.03.012.

[39] A.E. Franks, K.P. Nevin, Microbial fuel cells, a current review, Energies. 3 (2010) 899-919. https://doi.org/10.3390/en3050899.

[40] I. Gajda, J. Greenman, I.A. Ieropoulos, Recent advancements in real-world microbial fuel cell applications, Curr. Opin. Electrochem. 11 (2018) 78-83.

https://doi.org/10.1016/j.coelec.2018.09.006. 